\title{
EFL TEACHERS' UNDERSTANDING IN DEVELOPING LESSON PLAN
}

\author{
Annisa Putri \\ Indonesia University of Education, Bandung, Indonesia \\ Email: ichasofwan@gmail.com
}

APA Citation: Putri, A. (2016). EFL teachers' understanding in developing lesson plan. Indonesian EFLJournal, 2(1), 1-11

Received: 09-11-2015

Accepted: 22-12-2015

Published: 01-01-2016

\begin{abstract}
This research attempts to find out EFL teachers' understanding of lesson plan and the development along with problems the teachers faced in developing lesson plan. The researcher used two data collection techniques; interview and analyzing the lesson plan developed by four EFL teachers. The interview results revealed that all participants understand about the lesson plan as well as its development and understand about the elements that should be included as parts of lesson plan, but, unfortunately, the teachers could not understand the system of learning assessment. They thought that it is too complicated because they should provide one system of learning assessment along with the rubric of assessment. On the other hand, the result of lesson plan analysis showed that all participants understand how to develop lesson plan by stating all elements of lesson plan in accordance with the requirements stated in the Regulation of Ministry of Education and Culture No. 103 in 2014. The problems found are when the teachers did not state learning purposes, even two of the teachers stated that learning indicator is similar with learning purposes. Another problem is found when they did not include the assessment rubric. Then, the other problem is found when they were asked about the implementation of scientific approach. Scientific approach is a new thing for them to be applied as the approach consists of observing, questioning, associating, collecting, and communicating.

Keywords: lesson plan, lesson plan development, 2013 curriculum
\end{abstract}

\section{INTRODUCTION}

The 2013 curriculum, as quoted in Minister of Education and Culture Regulation no.59/2014 aims at "developing and equipping people in Indonesia with excellent characters such as faithful, productive, innovative, and creative in order to give meaningful and beneficial contribution to local, national, and international community." To reach the goal, teachers need to develop their innovative and creative plans to be applied in their teaching and learning process. The 2013 curriculum allows teachers to create and to develop their own lesson plan based on their school and students' needs (Syahmadi, 2013). Lesson plan must be arranged before entering classroom (Jalongo, et al., 2007). A teacher should consider that a learning process externally and internally happens inside the students themselves. It happens because of the influence coming from teachers, friends, students' surrounding, or students' curiosity. In the learning process, teachers need to consider the characteristics of material that students are going to learn. They also need to give learning experiences that are able to reveal, to develop, and to apply students' potential. Thus, it is important for a teacher to develop well learning plan that covers all of activities that can be applied to reach the learning experiences (Prihastuti, 2015). 
However, most of the teachers seem to be not ready to face the challenges from 2013 curriculum to develop their own lesson plan. Study conducted by Suhendra and Sundayana (2011) revealed that teachers' knowledge in developing lesson plan was not satisfying. Furthermore, Sundayana and Alwasilah (2012) found that teachers' conceptual understanding of designing, developing, and applying syllabus and lesson plan did not reach the expectation. Moreover, a preliminary research conducted by the researcher found that teachers in school faced difficult time in designing assessment for students' achievement since there are many assessments that should be conducted by the teachers such as portfolios, authentic assessment and writing or oral test, practice, projectbased, or self-assessment. Those techniques of assessment are very complicated, taking a long time, and it is hard for teachers to keep focus on the students (Nurfuadah, 2014).

Additionally, from the lesson plan analysis done in the preliminary research, it was found that there is incompatibility between the operational word (KKO) in KI and KD. Similar problem also found by Nurfuadah (2014) who said that the arrangement of core competence (KI) is not in accordance with the basic competence (KD). Meanwhile, Sumaryanto (2014) stated three main problems in designing lesson plan in 2013 curriculum including the relation between $\mathrm{KD}$, indicators, and learning purposes are not match, formulation or learning purposes are not appropriate with the learning activities, and the assessment instrument only uses test (essay or multiple choices).

Those problems became the basis of this research. The researcher thinks that it is important to conduct further study relating to teachers' understanding in developing lesson plan in 2013 curriculum. This research is expected to reveal teachers' understanding about lesson plan in 2013 curriculum, how they develop lesson plan, and the problems faced by them in developing lesson plan. Thus, this research is purposely designed to achieve the following objectives:

1. Find out EFL teachers' understanding about lesson plan in 2013 curriculum.

2. Find out how EFL teachers develop lesson plan of 2013 curriculum.

3. Find out the problems faced by EFL teachers in developing lesson plan.

\section{METHOD}

This research attempted to find out EFL teachers' understanding in developing lesson plan of 2013 curriculum along with the steps of developing lesson plan and the problems faced by them in developing lesson plan. This research dealt with qualitative as a research design which explores a problem and develop a detailed understanding of a central phenomenon (Bogdan \& Biklen, 1992; Thomas, 2003; Heigham \& Croker, 2009; Alwasilah, 2008; Creswell, 2012).

One pilot school was the site of this study. Meanwhile, the participants were all of EFL teachers (four teachers) in the pilot school. The participants have been teaching for more than 10 years, which means that they are already familiar with lesson plan. All teachers from every level were asked to give their brief understanding relating to the lesson plan development in 2013 curriculum.

\section{RESULTS AND DISCUSSION}

The data gathered from interview is attempted to get deep information relating to participants' understanding of lesson plan, the way they develop a lesson plan, and the problems faced by them in developing a lesson plan. The interview was conducted by asking 17 
questions to the participants. All questions have been categorized based on each point of information stated previously. Besides, the data gathered from analyzing the documents act as the triangulation. The result of the documents analysis shows the product of EFL teachers' understanding of lesson plan and the development of lesson plan.

\section{EFL Teachers' Understanding of Lesson Plan}

In order to find out EFL teachers' understanding of lesson plan, the researcher proposed several questions relating to their period of teaching, their training for implementing the new curriculum, and their understanding about lesson plan as the main component in implementing the curriculum. The four participants of this research are EFL teachers who have been teaching for years.

Regarding their period of teaching, all of the participants have different period of teaching. The first teacher has been teaching for 10 years, 25 years for the second teachers, 15 years for the third teacher, and 18 years for the fourth teacher. The participants come from a school. They have been given enough preparation by the school to develop lesson plan, including a meeting of teachers' association (MGMP) which helps them know all information about the curriculum and the lesson plan, and also gives the teachers a training to develop lesson plan. Besides, the researcher also proposed a question about the participants' understanding relating to what lesson plan is. It is important since developing lesson plan is the first step before the teachers conduct teaching-learning activity (Jalongo, et al., 2007).

The interview revealed that the teacher know that lesson plan is a teaching outline. They also know that they should develop lesson plan before they are going to the classroom. It is in line with Brown (1995) who states that lesson plan is used as a teaching framework. Celce-Murcia (2001) also supports by saying that a lesson plan is an extremely useful tool that servers as a combination guide, resource, and historical document reflecting our teaching philosophy, students population, textbooks, and our goals for our students. Teachers cannot be apart from lesson plan since lesson plan is their framework for teaching (Wyse, 2002).

In addition, from the lesson plans analyzed by the researcher, it showed that all of the participants understand the elements of lesson plan that should be included in a lesson plan such as school identity, identity of material/class/time allocation, core competences, basic competences, methods, materials, activities, and evaluations. Each participant clearly understands the importance of lesson plan to be described in detail. The more detail lesson plan is described, the more success the learning activities. It is in line with Scott and Ytreberg (2000) who mention that there are at least five advantages of lesson planning; making the lesson run smoothly, becoming more aware of how much time activities take, reflecting at the end of the lesson on what happened, anticipating how to balance the lesson, and giving the teacher time to observe what is going on.

\section{EFL Teachers' Understanding in Developing Lesson Plan}

Regarding the EFL teachers' understanding in developing lesson plan, Teacher 1 (T1) stated that lesson plan consists of several elements such as core competences, basic competences, 
purposes of learning, materials of learning, methods of learning, media and sources of learning, and assessment of learning. It is clear that the teacher know about the elements of lesson plan. It is in accordance with the elements of lesson plan proposed by the Regulation of Ministry of Education and Culture No. 65/ 2013 which consist of title, core competence, basic competence, learning indicator, teaching objectives, materials, time allocation, teaching method, procedures, assessment, and sources. There are 46 indicators which refer to each element of lesson plan.

The second question in interview relates to teachers' understanding about the steps in developing lesson plan. The interview result shows that teachers know that they should look into the four competences and the basic competences in regulation of ministry of education and culture number 59/2013 and number $69 / 2013$ as their guidance to develop learning purposes, learning materials, and learning resources to be used in learning activities and its assessments.

It means that teachers understand about the four competences and the basic competences mentioned in the regulation of ministry of education and culture number 69/2013. KI is formulated as Core competence-1 (KI-1) for core competence in spiritual aspect; Core competence-2 (KI-2) for core competence in social aspect; Core competence-3 (KI-3) for core competence in knowledge aspect; and Core competence-4 (KI-4) for core competence in skills aspects (Regulation of Ministry of Education and Culture No. 69/2013).

Basically, the teachers know that each core competence (KI), then, is formulated into the learning materials that the students should do as a form of standard competence of outcome (SKL). KI-3 (knowledge competence) and KI-4 (skill competences), then, are developed into basic competences (KD) and indicator of competence achievement (IPK) to determine the materials for learning activities. Meanwhile, KI-1 and KI-2 (spiritual and attitude competence) should be achieved by the students in form of nurturant effect and become their indirect teaching through learning activities developed by the teachers. Here, English competence for senior high school is divided into three types of discourse: interpersonal, transactional, and functional. Those competencies are required for oral and written communication acceptable in personal, social, cultural, and academic context. In other words, the classroom activity will involve the integration of four language skills; listening, speaking, reading, and writing.

Another question is related to teachers' understanding about indicators of achievement competence and learning purposes. Learning indicator is defined as specific statement of purposes in order to achieve certain goals (Richard, 2001). Reiser \& Dick (1996) says that objectives are explicit descriptions of what students will be able to do as a result of the instruction they received. It describes competences that the students are expected to demonstrate in accordance with the basic competence or known as performance objectives (Nunan, 1989; Rothwell \& Kazanas, 2009; Brady \& Kennedy, 2012). In 2013 curriculum, indicator of learning is called as Indicators of Competences Achievements (IPK). It shows the characteristics and the actions that will be done by the students and used as an indication that they have reach the basic competence. IPK is constructed based on the basic competences which are observable and measureable, involves affective, cognitive, and psychomotor domain (Regulation of 
Ministry of Education and Culture No. 65/2013).

In this research, 6 indicators has have been stated in accordance with the Regulation of Ministry of Education of Culture No. 65/ 2013. In case of Teacher 1, the three lesson plans did not stated the objectives which cover affective and psychomotor domain. The levels of competences for all three domains have been stated in the summary of KKO (Operational Words). For lesson plans developed by Teacher 2 , in his first lesson plans, there were no objectives which cover both affective and psychomotor domain. But in his second and third lesson plan, there were objectives which cover affective and psychomotor domain, Mengelola (A4 \& P5), Membiasakan (A4), Menentukan (P5), and Menunjukkan and Melengkapi (P2). Another case is Teacher 2 stated about objectives for KD-4, but there was no statement about KD-4 in the basic competence. For the lesson plans developed by Teacher 3, there was no statement of objectives which cover affective and psychomotor domains in the second lesson plan. But there were statements of objective which cover affective domains (offer, respond, and answer (A2)) in his first and third lesson plan. But, there were statements of objectives which cover psychomotor domain.

Lastly, in the lesson plan developed by Teacher 4 , there were no statements of objectives which cover affective and psychomotor domain in the first and third lesson plan. But there were statement of objectives which cover psychomotor domain in his second lesson plan (mencoba menirukan (P1)).

Further, to determine the teaching materials in a lesson plan, a teacher is suggested to provide the cognitive element or the factual knowledge to be taught and evaluated by the ability to recall (Piskurich, 2006). Besides, the teacher is demanded to present concept that what the learners can intellectually generalize from the content and evaluated by their ability to apply them on real or simulated situations (Adams, 2005). In addition, it is suggested that the teacher sequences the materials by considering the prerequisite relationships among the objectives, such as 1 ) the new learning is supported by previous learning, 2) doing a learning analysis to determine that the skills are being taught in a sequential order, 3) that the sequences are complete, and 4) that objectives irrelevant to the learning task at hand are eliminated or taught at a different time (Gagne et al., 1992). In 2013 curriculum, Learning materials are developed based on KD-3 and/or KD-4 along with KD-1 and KD-2 as the nurturant effects of students' learning result (Regulation of Ministry and Culture No. 65/ 2013). Learning materials can be in form of textbook and teacher's guide book, newspaper, news, movies, or other authentic materials, and students' environment.

In this research, there were six indicators of learning material' points checked in analyzing lesson plan which refer to learning materials. In lesson plans developed by Teacher 1 , almost all indicators were complete, except the indicator of "The teachers presented material from easy to difficult". All of three lesson plans did not state whether the teacher present the material sequential from easy to difficult. Moreover, in the second lesson plan, the teacher did not use authentic material.

Similar case found in lesson plans developed by Teacher 2 . The lesson plans did not state whether the teacher used sequential order to present materials from easy to difficult. In addition, in the first lesson plan, the teacher did not state 


\section{Annisa Putri}

EFL Teachers' Understanding in Developing Lesson Plan

appropriate learning strategy and did not use authentic material. Similar statement refers to the third lesson plan where the teacher stated she did not use authentic material. While, in the lesson plans developed by Teacher 3 and Teacher 4 , all indicators are almost complete, but they did not state that they presented materials from easy to difficult. All of the lesson plans did not state that the teacher used a sequence order to present material from the lower level to the higher. More, in first lesson plan developed by Teacher 4 , he did not state the appropriate strategy to present material and he did not use authentic material.

Learning activities consider learning approach, method, technique which persuades students' innovation, adaptation, and fun (Sundayana, 2009). Learning activities are constructed to guide the teacher during the teaching learning activities (Whitman, et. al., 1992) by considering the teaching methods and learning experiences that will best bring about the accomplishment of the aims and objectives (John, 2006; Johnson, 1989). The teachers should notice the model or learning method that will be used in classroom. In 2013 curriculum, model or learning methods are chosen based on the scientific approach which is needed to develop the competences (spiritual, social, knowledge, and skills). The decision of learning methods or models should consider the characteristics of KD or learning materials. The learning model is a form of learning that has a name, characteristics, syntax, settings, and culture for example, discovery learning, project-based learning, problem-based learning, or inquiry learning. In the case of lesson plans developed by the teachers in this research, they clearly stated about appropriate approach, method, strategy, or techniques.
In implementing lesson plan in the classroom, there are three activities that have to be covered, pre-activity, mainactivity, and post-activity (Syahmadi, 2013, see also Regulation of Ministry of Education No. 65/ 2013). In pre-activity, teacher have to create condition for an attractive learning, discuss previous competences relating to the next competences that will be learned by the students, inform competences that will be reached and their uses in daily life, inform the point of materials and the activities that will be conducted, and inform the techniques of assessment that will be used.

In this research, the lesson plans developed by Teacher 1 completed only 4 indicators. In her lesson plans, she did not state the indicator of giving motivation to the students and did not relate the current material to the previous lesson. On the other hand, first lesson plan developed by Teacher 2 was complete. The lesson plan completed all of indicators. But, in her second and third lesson plan, some indicators were incomplete. The teacher did not state that she gave motivation to the students and did not relate the current materials to the previous lesson. Similar case stated in third lesson plan. Lesson plans developed by Teacher 3 indicated that all indicators had been completed, except the indicator of relating current material to the previous lesson. All of the three lesson plans did not contain this indicator. On the other hand, the researcher found similar case between Teacher 1 and Teacher 4 in which two indicators of giving motivation to the students and relating material to the previous lesson were incomplete.

After conducting pre-activity for about 10 minutes (Woodward, 2009), the teacher may start to conduct mainactivity. This activity is conducted by presenting information or material and 
examples (Reiser \& Dick, 1996) or introducing the language form or content (Jensen, 2001).

Main activity is conducted based on students characteristics and covers three aspects of learning; attitude, knowledge, and skill (Syahmadi, 2013). Main activity can be conducted for about 70 percent of time allocated (McArdle, 2010). Main activity is a process of learning which is done interactively, attactively, inspirative, full of challenge, and actively motivates students to get involve in learning process (Regulation of Ministry of Education and Culture No. 65/ 2013). More, main activities provide students for having a space where they can develop their creativity and ability based on their talent, interest, and their psychology development.

In this research, the first lesson plan developed by Teacher 1 completed only four of six indicators of mainactivity. In the lesson plan, the teacher did not state how to manage classroom. Moreover, the lesson plan also did not state whether or not the students work in group, peer, or individual. Meanwhile, the lesson plan developed by Teacher 2 and Teacher 3 , all indicators in the lesson plan were complete. And for the lesson plan developed by Teacher 4, only one indicator was stated incompletely. The teacher did not mention whether the students work in group, peer, or individual.

Post activity or the closing part of an instructional event is the activities that may bring a lesson presentation to an appropriate conclusion (Cooper, 1990). Those closing activities will help students bring things together in their own mind to make sense out of what has been going on during the course of the presentation (Cooper, 1990).

There are three indicators analyzed relating to post-activity. In post-activity, the teachers are suggested to make conclusion of all materials learned, to give feedback or homework, and to inform the materials for the next meeting. As Reiser \& Dick (1996) states that in post-activity, teacher provides feedback and summarize or review the lesson (see also Woodward, 2009; Syahmadi, 2013). Teachers also give homework, write journals, and tidy up the classroom for the next teacher as well (Woordward, 2009). Regulation of Ministry of Education and Culture No. 65/ 2013 also mentions that in postactivity, teacher and the students summarize all of the learning materials, reflect all of the learning activities, and give feedback of the process and result of the learning. While for the teachers, they should assess students' works, plan the lesson for remedial program, and inform the plan of the lesson for the next meeting.

In this research, only the lesson plans developed by Teacher 1 indicating to be completed. All of the indicators have been stated in all lesson plans. Meanwhile, in case of lesson plans developed by Teacher 2 , the researcher found there was only one indicator that did not state in the second lesson plan. In this lesson plan, the teacher did not state that he gave information about materials for the next meeting. Further, in the lesson plan developed by Teacher 3 , his first lesson plan had completed all indicators. But in his second and third lesson plan, the last indicator was not stated. The lesson plans did not mention that the teacher gave information relating to the material for the next meeting. In case of Teacher 4, only the second lesson plan was indicated to be complete. While for the first and the third lesson plan, the last indicator was not stated in the lesson plan. The teacher did not give information related to material to be given in the next meeting. 
Lastly, assessment refers to a various ways of collecting information about students' language ability or achievement (Brindley, 2001). It is the tools of assessing whether students have achieved the learning goals and objectives or not (Reiser \& Dick, 1996); Hutchinson \& Water, 1994; Brown, 1995). Learning Outcomes Assessment by educators has a function to monitor the progress of learning, learning outcomes monitoring, and detecting needs improvement learning outcomes of students on an ongoing basis (Regulation of Ministry of Education and Culture No. 104/ 2014). The assessment of students learning achievement can be done based on the indicator which is developed from KD.

In this research, there were five indicators which were included into learning assessment. All lesson plans developed by the teachers were analyzed to know whether or not the learning assessment in the lesson plan has been in accordance with the indicators. In case of first lesson plan developed by Teacher 1 , three indicators were not complete. In the lesson plan, the teacher did not mention other technique of evaluation but observation. Besides, the teacher also did not complete the indicator 5 . The teacher did not state the rubric of evaluation. Meanwhile, in case of the second and third lesson plan, both lesson plan did not state rubric of evaluation by using practice and observation and did not mention how to evaluate students' learning outcome by using observation.

In case of lesson plans developed by Teacher 2,3 , and 4 , the three lesson plans have completed all indicators of learning evaluation. All lesson plans stated types of assessment used to assess students' learning outcome. Variety of evaluation also stated clearly in the lesson plans. All assessments were in accordance with teaching objectives. The teacher also clearly stated the instruments used to assess the students' learning outcome. The statements of rubrics were also clearly stated. The teachers stated the rubric used to assess the student' learning outcome by using observation and practice.

\section{EFL Teachers' Problems in Developing Lesson Plan}

In developing lesson plan, teachers revealed that they have some problems. The problems came up when they have to integrate scientific structure into learning activities. Learning activities is arranged to reach basic competence (KD) by giving learning experience which involves the mental and physical processes through the interaction between the students, teachers, environment, and other learning sources. The learning experiences can be achieved by using scientific approach or methods, or by giving various learning experience based on students' first potential and learning material's characteristics. In developing the learning activities, teachers should consider several aspects, there are 1) learning activities should be arranged as a guidance for teachers to conduct effective learning, 2) learning activities should cover a sequence of manageable activities which are done by students and teachers in order to achieve learning purpose, 3) learning activities in every meeting are a scenario, by using scientific approaches, that leads the students to be active in learning and apply their knowledge.

Another problem came up when the teachers have to use variety of learning assessments. As we know that each learning assessment techniques have different process to assess, as well as the rubric. As the Regulation of Ministry of Education and Culture Number 104/2014 mentions that several 
techniques of assessment can be conducted to assess students' learning outcome and the use of those learning assessment techniques should be in accordance with the indicators which are based on the KD, authentic assessment and writing or oral test, practice, projectbased, portfolio, or self-assessment. Authentic assessment is a form of assessment that demands the students to perform attitude, use the knowledge, and apply the skills in a real context. Meanwhile, self-assessment is a kind of reflective assessment to see students' attitude, knowledge, and skills inside themselves. Besides, there is homework, which is used to assess students' task done in group or by themselves. On the other hand, project can be done to assess students' project starting from the planning, conducting, data analyzing, and reporting. The criteria of assessment are based on students learning product that they have achieved after finishing the learning processes. The result of assessment, then, will be analyzed to decide whether KD has been achieved or not. In case of KD has not been reached, the teacher can give remedial program. The assessment system should be based on what students have done in learning process. The solution for the problems that the teachers faced in developing lesson plan is by having discussion with other teachers in school or in teacher association (MGMP).

\section{CONCLUSION}

While the data gathered from document analysis, it is found that all teachers have complete the structure of lesson plan mentioned in the Regulation of Ministry of Education and Culture number 103/ 2014 about the guide of learning implementation. The researcher analyze three lesson plans as the representative of lesson plan in the beginning semester, mid-semester, and the final semester. The lesson plans are analyzed based on the elements of lesson plan. All of the teachers stated school identity, learning subject, and class/semester; time allocation; core competence (KI), basic competence (KD), indicators of competences achievement (IPK); learning materials; learning activities; assessments; and learning sources and media. Related to learning materials, two of the teachers did not mentioned clearly about the materials in detail. Related to learning indicator and learning purposes, all teachers only mention the learning indicator, but it is stated in a specific operational sentences which belong to learning purposes. Both two terms supposed to be mentioned differently. As Reiser \& Dick (1996) says that learning objectives are explicit descriptions of what students will be able to do as a result of the instruction they receive. Learning objectives are statements of observable and measurable behaviors (Gagne et al., 1992). It describes competences that the students are expected to demonstrate in accordance with the basic competence or known as performance objectives (Nunan, 1989; Rothwell \& Kazanas, 2009; Brady \& Kennedy, 2012). Further, the learning objectives must be written in observable terms, student - oriented (Cooper, 1990; Piskurich, 2006), cover three domains of objectives, namely: cognitive, affective, and psychomotor (Posner, 1992), and stated in action verbs (Cooper, 1990).

From the result of interview, it reveals that all the teachers have problems when they have to integrated scientific approach in learning activity. Besides, the teachers also faced a problem when they have to adjust the learning method with the assessment technique. As Ministry of Education and Culture Regulation no. 104/ 2014 states some assessments that are used to assess 


\section{Annisa Putri}

EFL Teachers' Understanding in Developing Lesson Plan

students' achievement, such as authentic assessment and writing or oral test, practice, project-based, portfolio, or selfassessment. Authentic assessment is a form of assessment that demands the students to perform attitude, use the knowledge, and apply the skills in a real context. Meanwhile, self-assessment is a kind of reflective assessment to see students' attitude, knowledge, and skills inside themselves. Besides, there is homework, which is used to assess students' task done in group or by themselves. On the other hand, project can be done to assess students' project starting from the planning, conducting, data analyzing, and reporting. But those techniques of assessment are complicated for them.

\section{REFERENCES}

Alwasilah, C. (2008). Dasar-dasar merancang dan melakukan penelitian kualitatif. Jakarta: Pustaka Jaya.

Brady, L., \& Kennedy, K. (2012). Curriculum construction. Sidney: Pearson.

Brindley, G. (2001). Assessment. Cambridge: Cambridge University Press.

Cooper, J. (1990). Classroom teaching skills. Canada: D.C. Health and Company.

Gagne, R., Wager, W., Golas, K., \& Keller, J. (1992). Principles of instructional design. Orlando: Harcourt Brace Jovanovich College Publishers.

Heigham, J., \& Croker, R. A. (2009). Qualitative research in applied linguistcs: A practical introduction. United Kingdon: Palgrave Macmillan.

Jalongo, M., Rieg, S., \& Heltebran, V. (2007). Planning for learning: Collaborative approaches to lesson design and review. New York: Teachers College Press.

McArdle, G. (2010). Instructional design for action learning. New York: Amacom.

Nunan, D. (1989). Learner-centered curriculum design. Cambridge: Cambridge University Press.

Nurfuadah, R. N. (2014). 10 masalah utama kurikulum 2013. Retrieved December 4, 2015, from http://news.okezone.com
Posner, G. J. (1992). Analyzing the curriculum. New York: McGraw-Hill, Inc.

Prihastuti, I. (2015). Analisis rencana pelaksanaan pembelajaran (RPP) tematik yang disusun guru pada diklat implementasi kurikulum 2013. Retrieved December 8, 2015, from http://lpmpbanten.net

Regulation of Ministry of Education and Culture No. 103/ 2014 about Learning System for Elementary and Middle School.

Regulation of Ministry of Education and Culture No. 104/ 2014 about Learning Assessment System.

Regulation of Ministry of Education and Culture No. 65/ 2013 about Standard Process.

Reiser, R., \& Dick, W. (1996). Instructional planning: A guide for teachers. Boston: Allyn and Bacon.

Rothwell, W., \& Kazanas, H. C. (2009). Mastering the instructional design process: A systematic approach.

Suhendra, Y., \& Sundayana, W. (2011). Pengembangan model bahan ajar literasi membaca berdasarkan model PISA 2009 bagi siswa SMP RSBI di Jawa Barat. Jakarta: Pusat Penilaian Pendidikan DEPDIKNAS.

Sundayana, W. (2009). Persepsi guru dan kesulitan guru bahasa Inggris SMP/MTs di Jawa Barat dalam pengembangan kurikulum tingkat satuan pendidikan. Bandung: HIPKIN.

Sundayana, W., \& Alwasilah, A. C. (2012). Pemahaman konseptual guru terhadap desain, pengembangan, dan penerapan perangkat pembelajaran. Bandung: LPPM UPI.

Syahmadi, H. (2013). Bedah curriculum 2013 bagi guru bahasa Inggris. Bandung: ADOYA Mitra Sejahtera.

Woodward, T. (2009). Planning lesson and courses: Designing sequence of work for the language classroom. New York: Cambridge University Press.

Wyse, D. (2002). Becoming a primary school teacher. New York: Rotledge. 